\title{
ACCOUNTING AUTOMATION AND THE FUTURE OF THE ACCOUNTING PROFESSION
}

\section{ORIGINAL ARTICLE}

SUMAR, Ramiro Rodrigues ${ }^{1}$

SUMAR, Ramiro Rodrigues. Accounting Automation and the Future of the Accounting Profession. Revista Científica Multidisciplinar Núcleo do Conhecimento. Year 06, Ed. 06, Vol. 17, pp. 167-181. June 2021. ISSN: 2448-0959, Access Link: https://www.nucleodoconhecimento.com.br/accounting/accounting-profession, DOI: 10.32749/nucleodoconhecimento.com.br/accounting/accounting-profession

\section{ABSTRACT}

The presence of quality in the services provided is indeed indispensable for the survival of the accounting profession, since it translates into the objective of an accountant. Information systems, new artificial intelligence technologies and innovation, when connected with the expertise of accounting professionals, can result in greater performance of companies and, consequently, the economy. Considering that the profession of the accountant seeks to provide tax information to the tax authorities, this article aims to demonstrate that this profession is in a process of migration with regard to the automation of tasks, in order to become a management tool capable of assisting in assertive decision-making, in order to contribute to the performance of the companies' social responsibility. The problematization of this study is based on the following problem question: What will be the role of the accountant with the automation of accounting? Will the accounting profession end as predicted by the Sapiens Institute in 2018 research? To achieve the objectives, the literature review was used. As results, the article demonstrated the role of the accountant in the process of development and growth of companies before and after the automation of bureaucratic processes, as

\footnotetext{
${ }^{1}$ Master's degree in Controllership, Specialist in Technology Management, Strategic Administration, Information Security and Graduated in Accounting Sciences.
}

RC: 91613

Disponível em: https://www.nucleodoconhecimento.com.br/accounting/accounting-profession 
well as the perspective of future scenario of the profession. Thus, it was found that the accounting profession undergoes a sudden change of positioning so that it survives as a profession and maintains its role with the society and economy of the country.

Keywords: Accounting Automation, Accounting Professional, Social Responsibility, Decision Making.

\section{INTRODUCTION}

There is a scenario of great changes in the accounting market, with new technologies, use of artificial intelligence and process automation. And along with these changes are the concerns, anxieties and uncertainties that the new arouses in people (SOUZA et al., 2018).

These changes in the country are seen and felt by all, where inflation is no longer considered a problem, unemployment rates have decreased, access to credit and consumption has increased and as a consequence poverty rates have decreased (CUNHA, 2019).

Therefore, there is an entrepreneurial scenario, in which new companies emerge every day and more professionals are requested, but some professions run the risk of nonexisting due to technology and automation (LEITE, 2017; ARAÚJO, 2020).

According to Rozenbaum (2018), a study conducted in 2018 by the French institute Sapiens reveals that five professions are at risk of being extinguished, among them is the accounting professional who works in an office without access to technology, such as the use of computers.

The modern accountant, still has to deal with the bureaucratic part, the legalities and large amount of roles that occupy space. Since the automation of processes and other advents to facilitate accounting work are derived from technologies, the accounting professional will have to adapt to the use of technology to his advantage, or be reluctant to change and see his profession disappear before automation (DINIZ, 2014). 
According to the study by the French institute, a number above two million people "are strongly likely to see their jobs disappear in the coming years." The data for the study were from the DARES (Statistical Studies Service of the French Ministry of Labor) and in it, for example, it can be observed that bank workers can disappear completely by 2050 and accountants in 2056 (ROZENBAUM, 2018).

The competitiveness exposed in the market, with entrepreneurs seeking innovation and new technologies every day to expand their business, makes the accounting professional inserted in this environment. Companies facing the competitive market can not fail to have alongside the help of the accountant, since this professional has in his attribution aim at quality and efficiency in all areas of the business (CHIAVENATO, 2004).

Another point is that millennials are taking over the labor market and gaining positions in the hierarchy of companies and in decision-making. So for the accounting professional it is important to know and understand this audience who expect agility and quality in accounting services.

However, the purpose of this article is to study the future of the accounting profession and the automation that has been occurring in accounting work. These changes are necessary to keep the accountant in the competitive market, as well as its importance in generating new jobs, its ability to undertake and innovate, as well as the social importance before its accounting and fiscal function.

The accounting profession is going through major transformations, no longer being the professional who only brings problems and accounts, and acting as support in the management of companies. To this end, the professional must adapt to the new requirements and innovate, in order to maintain its role and importance, not only for companies and managers, but also for society, after its social role.

The methodology used in the writing of this article was bibliographic research, through annais, research, books, magazines, internet interviews, internet articles and published academic articles. For Gil (2008), bibliographic research is developed based 
on material already elaborated and composed mainly of monographs, dissertations, scientific articles and books.

When it comes to purpose, Marconi and Lakatos (1992) explain that bibliographic research makes the observer have the opportunity to contact directly with the materials written on the subject of the research and assist the researcher in his analysis or at the time of manipulation of the information. Bibliographic research is considered as the first step towards the initiation of scientific research.

\section{THEORETICAL REFERENCE}

\subsection{HISTORY OF THE ACCOUNTING PROFESSIONAL}

There are reports that the figure of the accountant has been present since the beginning of civilization. According to ludícibus and Marion (2006, p. 32): "[...] from the most primitive peoples, Accounting already existed due to the need to control, measure and preserve family assets and even, because of exchanging goods for greater people's satisfaction [...]".

Despite the reports, the official existence of accounting was marked in the modern age, in the 15th to 16th centuries, in the region of Italy. In the renaissance period, the accounting profession gained space in areas such as: economics, arts, sciences and technologies (FIGUEIREDO; STRASSBURG, 2008).

In Brazil, even before the first commercial technical schools appeared, accounting was practiced by the figure of the "bookkeeper", a professional defined according to the Commercial Code of 1850 who, according to Francisco D'Auria (1949), took care of and recorded the transactions of commercial establishments at that time (CARVALHO, 2017).

The development of the accounting profession followed the approval of Decree-Law No. 9,295 of May 27, 1946, which created the Federal Accounting Council and defined 
the attributions of accountants, accounting technicians and bookkeepers (DOS SANTOS et al., 2019).

With the council the profession expanded and many problems arose with the equalization of professionals with different levels of education and knowledge. If, on the one hand, there is the accountant trained with an undergraduate course, a professional without any study coexisted in the same profession (NETO, 2010).

This caused the disinterest of young people in accounting, since the status of this profession was not the same as that of other formations such as Law and Economics. How to arouse interest in a profession that presents levels of professionals opposed to each other? This was only possible with proof of proficiency and separation from accounting technician to accountant itself.

In 1972, the audit was regulated through Resolution No. 220, as well as Circulars No. 178 and No. 179 of the Central Bank of Brazil. It imposed demonstrative standards that required professionals to be adapted to an audit by certified persons (ABREU, 2013; CORDEIRO, 2011).

However, the accounting profession received status only in December 1976 with the enactment of Law 6,404 known as the SA (Sociedades Anônimas - Anonymous society) Law. This law originated the Brazilian Securities and Exchange Commission (CVM), which replaced the Central Bank, regarding the issuance of opinions and part of the accounting legislation, as well as the control of the capital market in Brazil (CARVALHOSA, 2017).

For Santos (2008, p. 9)

[...] in recent years, especially after the end of the era of high inflation, from the mid-1990s, it has undergone a period of great changes and adaptations. Companies that were more agile in adjusting their focus to their core business, their core business, and no longer managing inflationary earnings and revenues, achieved higher success rate. And, at this moment, the accounting professional has a primary participation when providing tax, corporate and financial guidance. [...]. The counter, increasingly, is the compass of the company. 
It is observed that the skills and skills requirements of the accounting professional are focused on strategies and decision-making in companies. Due to technological changes, governments, companies and managers are in a high degree of innovation, increasingly demanding from the accounting professional who, in turn, assist decisionmaking (DE OLIVEIRA REIS et al., 2015).

In a highly competitive and agile environment, obtaining information safely is a differential. Accuracy and reliability are also required by modern companies that want to ensure their survival in the market and make the accountant figure a wealth data scientist and accounting entries, requiring him to know how to interpret the data and outline strategies and paths that ensure better results. All these demands come against what Santos $(2008$, p. 10) writes in his book:

[...] the counter should not lose from mind that accounting is not for it, it is for the user. Accounting is the language of business and this language tells the story of each company. Perfecting this language seeking to increase its power of prediction and utility to the user is perhaps the main mission of the accountant. [...]

Therefore, the professional must be in the process of learning, updating and education to be an expert in his/her role and in obtaining data that helps the corporation in its social objective. The easy access to postgraduate courses in the area of accounting brings the individual the opportunity to be positioned next to the market to contribute to companies, the economy and society.

\subsection{ECONOMIC DEVELOPMENT AND GROWTH}

Furtado (1964) defines economic development as "a process of social change by which an increasing number of human needs are satisfied through a differentiation in the productive system resulting from the introduction of technological innovations".

For Hewlett (1981), economic development is defined as "a significant increase in a nation's real per capita income, with the purpose of obtaining better food, health, education, better living conditions and an ever wider range of work and leisure opportunities for the people of this nation." 
On the other hand, there is economic growth that, according to Siedenberg (2006), consists of a "process of changes of predominantly quantitative character, meaning an increase in size, volume and/or quantity". Summarizing what Vasconcellos (2000) concluded, pointing out that economic growth is the continuous growth of per capita income over a time.

The growth and maintenance of gross domestic product (GDP) promote a higher quality of life for the population. In addition, technological innovations, increased national revenue, expansion of the workforce and savings are other factors that help in a country's economic growth.

It is observed that when a country shows economic growth the number of unemployed people decreases, while the taxes collected increase. In this context, there is a need to invest more to maintain the continued growth of the economy. Mendes (2015) explains that the economy and the growth of parents have underperformed due to some factors, including education and high tax burden.

Aligned with economic growth comes the economic development that to exist it is necessary for the country to maintain indicators and have factors for improving the quality of life and income of the population over time. For Rocha (2004) what demonstrates these factors is: the growth of economic well-being, measured through economic indicators, among which it is valid to mention the total national product and the national product per capita; reducing levels of poverty, unemployment and social life; and the increase in health, nutrition, education and housing conditions.

The Human Development Index - HDI, of the United Nations (UN), is a measurement unit created and used to verify the degree of development of a given country, covering health, education and income. The index is a numerical reference that has its variation defined between 0 and 1 , in its definitions, the closer the value is to 1 , the better should be the development of that location in the presented items. No country has an HDI defined at zero or even one (FILGUEIRA et al., 2010). 
According to the UN report that has the evaluation of 189 countries, Brazil reached 0.761 points in 2018 , which represents a significant increase compared to 2013 , where it received 0.752 .

Brazil's position is 79th in the ranking, alongside Colombia and ranked among the countries of high human development category. In the report the highest indicator is that of Norway with 0.954 points, and listed with the worst human development index is Niger with 0.377 (LEUSIN JÚNIOR, 2015).

\subsection{NEW TECHNOLOGIES IN ACCOUNTING}

New technologies end up generating structural changes in organizations with their application, impacting on companies' costs and modifying their production processes, in view of competitiveness in the market (MAT, 2010).

Scott (2009) emphasizes that the use of technology in accounting is an unprecedented change, that is, it is not easy to identify whether its impacts were negative or positive. From another point of view, Alsharayri (2011) and Choe (2004) show that the level of technology and information produced have positive impacts.

Technology has positive impacts on both agility and reliability and the security of information systems used in companies by accounting offices and professionals. The function of the information generated by the systems, according to Allahyari and Ramazani (2011), is to help its users make decisions, considering that accounting is able to produce information relevant to the formulation of business and strategic processes, for the control of activities and for the growth of companies.

For Scott (2009), the advantage of technology lies in the use of several tools to speed up the execution of functions performed by the counter. In this aspect, technology contributes to the operational advancement of accounting in the face of competitiveness, given the speed and efficiency offered by technological advances. 
Acevedo (2012) shows that if communications in accounting companies are fast they can help increase productivity, as well as can improve decision-making and facilitate business growth.

Also according to Scott (2009), one disadvantage of technology is its dependence on humans. Technology arises from human innovation, therefore, it is a product that repeats the same human errors. But this can be circumvented with more robust processes and with a more focused specialization and education on automation. It also demonstrates that another disadvantage is the dependence of the profession on technology, but it is already known that studies show that the counter that existed to operationalize calculations will become extinct, which comes against this erroneous thought of the author.

Aribaba et al. (2011), in turn, highlight the importance that technology adds to society, especially in small service companies, given the improvement in performance and greater business development. Thus, with more performance arise more opportunity and gains, with this jobs are generated and the economy is benefited.

Competitiveness requires accounting organizations to be able to create value for their customers. These customers who are tax payers and staff contractors. According to Simons (1987), by differentiating themselves from their competitors, implementing and formulating a well-defined business strategy, these organizations will add more results. In the strategy, the use of technologies added to accounting systems is essential, since it provides safe and useful information (JERMIAS; GANI; 2004).

Having a well-defined and consolidated strategy, based on investments in technology and people qualification, according to Grande et al. (2011), will bring productive advantages and favorable changes for its customers compared to its competitors.

\subsection{ROLE OF THE ACCOUNTANT IN INNOVATION AND AUTOMATION OF ACCOUNTING PROCESSES}


The numbers of accounting offices increase and contribute to the decrease in unemployment, between the years 2009 to 2012, according to Gondim (2014). There was an increase in more than $60 \%$ of formal jobs and $5 \%$ in new accounting firms.

The Federal Accounting Council (CFC, 2014), presents, in its portal, a research conducted that demonstrates that more than $58 \%$ of accounting professionals have the preference to work in private sector companies or open their own office to have to tender and enter the public sector. See that these data show the contribution to the generation of formal and informal employment numbers, since the accounting professional works with the managers of companies (their clients) collaborating so that the business evolves and grows and needs more employees.

By helping entrepreneurs or investing in their own business, using practical and theoretical knowledge acquired, the accountant has a significant role in the economy. In recent years accounting has stopped only using a calculator and reams of paper (NOGUEIRA, 2010).

See that Coelho (2015) explains that the accountant went from being the person who records past facts to being a strategic consultant with a prospective and broad view of the market. Based on these changes the contactor has the mission of automating processes, generating more performance and comcomworking statistical data in order to support companies and managers in decision making.

Fávero et al. (2006) show that "accounting aims to generate information for the various users so that they can make decisions". This objective seems simple, but the subjective factors involved in it make this process difficult, the difficulty of understanding the data and the distancing of the manager's accountant makes this objective difficult to be fulfilled. Let's see that there are variables for good communication, and these must be studied and the accountant's specialty, so that his goal, as an accounting professional, is achieved.

As a target audience of accounting information identifies the new generation that needs reliable information and requires it to be quickly, coming against Drucker (1987), the 
specific job of the entrepreneur manager of a company is to make the business of this company become more agile and quality.

According to data available on the CFC website (2014), Brazil currently has more than 71,008 accounting organizations/companies and 515,011 professionals registered with the Federal Accounting Council and these professionals and offices must be prepared for the automation of processes.

Having the accountant the function of guiding managers to the growth of their companies, this professional also plays an important role in society, and for this, should always be in search of updating their knowledge and behaving ethically, being the interlocutor of the government, with the taxpayer and society (CORONADO, 2017).

The accountant who guides his clients to contribute correctly, helps in the development of the state and with this in the development of the country. In this role, automation is the key to all the attention of the accountant is in the generation of information and not in boring and time-consuming tasks of conferences and releases.

Competence, professionalism, agility and specialization of those involved in the processes make them more coherent, agile and function correctly. Efficient and specialized accounting practice is the point that should be paid attention to the business perpetuato and are increasingly efficient and competitive.

The professional who understands these behavioral changes that has been happening, specializes and updates, will have an important and decisive role in society and corporations. The whole process depends on a human being, and this, human being has to have the skills and skills for the automated process to work properly, in addition to a systemic knowledge of companies. Specialization and in-depth knowledge are tools for this new paradigm of change in the accounting profession.

\section{CONCLUSION}

As stated in this article, the accounting profession from the beginning is important for the development and growth of the country. The automation of accounting processes 
and the change of requirements of the profession will make the professional who today is seen as only the complying with legal requirements be extinguished. Then comes the opportunity for the profession and professionals to stand out in other areas of their knowledge such as consulting and business strategy, putting the vast knowledge acquired in education for training.

Accounting offices contribute to the generation of jobs, thus fulfilling their social role, but must adapt to the new dynamics of information systems so that they are efficient and produce with quality and agility the information necessary for companies and governments. Since education is a foundation for the development of any nation, the improvement of the profession and education of the professional entails a significant improvement in the base of society and with it events of social and professional improvement.

The accounting professional has ceased to be the one who only brings bad news to companies, with guides and accounts payable, providing a strategic orientation to entrepreneurs and managers, contributing to them perform their functions correctly and with the agility that the market requires through correct data and extracted quickly.

Contador has all the tools and knowledge to automate the preparation of financial statements and releases, in order to bring more agility and reliability, thus emerges as an ally for companies to play their social role with business growth.

Companies growing solidly, intelligently and fulfilling their tax and corporate obligations with quality and agility, a role that the accountant can play along with management, will make the whole society develop. If everyone is fulfilling their role with the economy and society, new jobs will be generated, more taxes will be paid, poverty rates will decrease and educational supply will be higher.

The threat of non-existence of the profession will cause professionals to reinvent themselves and review their position in the face of innovations. Those who have a different view of their position as an accounting professional, combining with new technologies of artificial intelligence, automation and specialization have gained space 
in the market, different from the professional who is oblivious to the changes and fight against them.

On the other hand, accounting education needs to be improved, so that new technologies are used in teaching and for trainees to leave universities prepared to face the current world that requires agility and quality in the provision of services.

A gap to be studied is observed regarding the demographic distribution of accounting professionals, given the degree of innovation of companies in certain regions. This will give a broader view of what may or may not occur with the career. It is also suggested to conduct case studies in innovative companies with a high degree of automation and the positioning of the professional towards this company and its results. These studies will contribute to a broader understanding of what may occur in the future.

\section{REFERENCES}

ABREU, E. N. de. Regulamentação de auditoria: estudo da influência das fraudes contábeis de 2001. Goiânia: Universidade Federal de Goiás - UFG, 2013.

ACEVEDO, L. Business benefits of information technology. Chron, 2019. Disponível em: <http://smallbusiness.chron.com/business-benefits-informationtechnology-4021.html . Acesso em: 10/mai/2021

ALLAHYARI, A.; RAMAZANI, M. Firm technological change and its effects on management accounting change: case study of Iranian manufacturing firms. Global Journal of Management and Business Research, v. 11, n. 9, 2011.

ALSHARAYRI, M. A. The E-Commerce impact on improving accounting information system in Jordanian Hotels. International Research Journal of Finance and Economics, v. 75, 2011.

ARAÚJO, F. M. de. A inteligência artificial e os seus impactos no mundo do trabalho. Fortaleza: Centro Universitário Fametro, 2020. 
ARIBABA, F. et al. An evaluation of the impact of technological innovative entrepreneurial development programmes on the performance of small scale business in Nigeria. Global Journal of Business, Management And Accounting, v. 1, n. 1, 2011.

CARVALHOSA, M. de S. B. Comentários à lei de sociedades anônimas. Saraiva Educação SA, Editora: Saraiva Educação S. A., v. 1. 2017.

CFC. Conselho Federal de Contabilidade. Dados estatísticos do Conselho Federal de Contabilidade. 2014. Disponível em: http://www.cfc.org.br/. Acesso em: 12/mai/2021

CHIAVENATO, I. Empreendedorismo: dando asas ao espírito empreendedor. Editora manole, 4를 2004.

$\mathrm{CHOE}, \mathrm{J}$. Impact of management accounting information and AMT on organizational performance. Journal of Information Technology, v. 19, 2004.

COELHO, J. M. A. Contabilidade: uma carreira em transformação. Disponível em: http://www.portalcfc.org.br/noticia.php?new=23196. Acesso em: 12/mai/2021.

CORDEIRO, C. M. R. Auditoria e Governança corporativa. Editora: IESDE, 2011.

CORONADO, O. Contabilidade gerencial básica. Editora: Saraiva Educação SA, 2017.

CUNHA, E. S. Oferta de crédito e emprego local nos municípios da região Nordeste: 2002-2015. Salvador: Federal da Bahia. 2019.

D'AURIA, F. Primeiros princípios de contabilidade pura. São Paulo: Departamento de Cultura e Ação Social, 1949.

DE OLIVEIRA REIS, A. et al. Perfil do profissional contábil: habilidades, competências e imagem simbólica. Revista Contemporânea de contabilidade, v. 12, n. 25, p. 95-116, 2015. 
DINIZ, E. R. da S. et al. Governança eletrônica no Brasil e o papel das tecnologias da informação e comunicação. Florianópolis: Universidade Federal de Santa Catarina, 2014.

DOS SANTOS, M. J. A. et al. Um estudo comparativo entre o exame de suficiência do conselho federal de contabilidade, o exame nacional de desempenho de estudantes e a pós-graduação stricto sensu dos cursos de ciências contábeis do Estado do Rio de Janeiro. Polêm!ca, v. 13, n. 4, p. 1681-1698, 2014.

DRUCKER, P. F. Inovação e Espírito Empreendedor: prática e princípios. São Paulo: Pioneira, 1987.

FAVERO, H. L. et al. Teoria e Prática. 4 ed. Editora: Atlas, São Paulo. 2006.

FIGUEIREDO, C. R.; STRASSBURG, U. A Contabilidade: aspectos históricos que influenciaram no seu desenvolvimento no decorrer do tempo. IX Jornada de Estudos Contábeis-UNIOESTE, 2008.

FILGUEIRA, J. M. et al. Um panorama estatístico de cunho econômico, social e educacional do estado do Rio Grande do Norte. HOLOS, v. 4, p. 198-215, 2010.

FURTADO, C. Dialética do Desenvolvimento. Rio de Janeiro, $2^{\underline{a}}$ ed., Fundo de Cultura, 1964.

GIL, A. C. Métodos e técnicas de pesquisa social. 6. ed. São Paulo: Atlas, 2008.

GONDIM, A. MEl também tem obrigações fiscais. Contábeis, 2016. Disponível em: https://www.contabeis.com.br/noticias/26714/mei-tambem-tem-obrigacoes-fiscais/.

GRANDE, E. U. et al. The impact of accounting information systems (AIS) on performance measures: empirical evidence in Spanish SMEs. The International Journal of Digital Accounting Research, v. 11, 2011.

HEWLETT, S. A. Dilemas do desenvolvimento. Rio de Janeiro: Zahar, 1981. 
IUDÍCIBUS, S. de; MARION, J. C. Introdução à teoria da contabilidade para o nível de graduação. 4 ed. São Paulo. Editora: Atlas, 2006.

JERMIAS, J.; GANI, L. Integrating business strategy, organizational configurations and management accounting systems with business unit effectiveness: a fitness landscape approach. Management Accounting Research, v. 15, 2004.

LEITE, E. F. O fenômeno do empreendedorismo. Saraiva Educação SA, 2017.

LEUSIN JÚNIOR, S. A inserção internacional de potências médias: evidências da afirmação de países em desenvolvimento a luz da evolução do sistema multilateral de comércio. Porto Alegre: Universidade Federal do Rio Grande do Sul, 2015.

MARCONI, M. de A.; LAKATOS, E. M. Metodologia do trabalho científico. São Paulo: Editora Atlas, 1992. 4a ed.

MAT, T. Z. Management accounting and organizational change: impact of alignment of management accounting system, structure and strategy on performance. Philosophy School of Accounting, Finance and Economics Faculty of Business and Law Edith Cowan University. Perth Western Austrália, 2010.

MENDES, M. Por que a economia do Brasil foi para o buraco? Brasil economia e governo, 2015. Disponível em: http://www.brasil-economiagoverno.org.br/2015/08/25/por-que-a-economia-brasileira-foi-para-o-buraco/. Acesso em: 14/mai/2021.

NETO, O. R. M. A profissionalização do contador no Brasil. São Paulo: Mackpesquisa, $2010 . \quad$ Disponível em: http://168.197.92.160/bitstream/handle/10899/14605/721_2008_0_15.pdf?sequence $=1$ \&isAllowed $=\mathrm{y} /$. Acesso em: $14 / \mathrm{mai} / 2021$. 
NOGUEIRA, M. Práticas de contabilidade: relatório de estágio do Mestrado em Gestão. Coimbra: [s.n], 2010.

RAMALHO, T. C. L. Contabilidade criativa: a percepção dos Técnicos Oficiais de Contas. Lisboa: Instituto Superior de Contabilidade e Administração de Lisboa. 2015.

ROCHA, F. J. M. Educação e economia: uma abordagem sobre as consequências e condicionantes econômicas do desenvolvimento humano, com ênfase em educação. Brasília: Cadastro de Finanças Públicas, n. 5, 2004.

ROZENBAUM, S. Revolução digital deixa cinco profissões à beira da extinção. rfi, 2018. Disponível em: https://www.rfi.fr/br/economia/20180829-revolucao-digitaldeixa-cinco-profissoes-beira-da-extincao-diz-estudo.

SANTOS, R. F. dos. Introdução à contabilidade: noções fundamentais. São Paulo: Saraiva, 2008.

SCOTT, W. The impact technology is having on the accounting profession. World conference on higher education, 2009.

SIEDENBERG, D. R. Dicionário do Desenvolvimento Regional. Santa Cruz: Edunisc, 2006.

SIMONS, R. Accounting control systems and business strategy: an empirical analysis. Accounting, Organizations and Society, v. 12,1987.

SOUZA, E. C. et al. As características qualitativas da informação contábil a partir da percepção dos profissionais de contabilidade. In: Congresso UFPE de Ciências Contábeis. 2018.

VASCONCELLOS, M. A. S. de. Economia Micro e Macro: Teoria e Exercícios, Glossário com 260 Principais Conceitos Econômicos. São Paulo: Atlas, 2000.

Submitted: August, 2020. 
Approved: June, 2021. 